\title{
Cameroon-Nigeria Border Conflict Incidence on Trade Patterns and Dynamics Within Near-Border Settlements of the Bakassi Peninsula, Cameroon
}

\author{
Jude Ndzifon Kimengsi ${ }^{1, ~ *, ~ Z e p h a n i a ~ N j i ~ F o g w e ~}{ }^{2}$, Nebota Catherine Mende ${ }^{2}$ \\ ${ }^{1}$ Department of Geography and Environmental Studies, Catholic University of Cameroon, Bamenda, Cameroon \\ ${ }^{2}$ Department of Geography and Planning, University of Bamenda, Bambili, Cameroon \\ Email address: \\ jude.kimengsi@catuc.org (J. N. Kimengsi) \\ ${ }^{*}$ Corresponding author
}

\section{To cite this article:}

Jude Ndzifon Kimengsi, Zephania Nji Fogwe, Nebota Catherine Mende. Cameroon-Nigeria Border Conflict Incidence on Trade Patterns and Dynamics Within Near-Border Settlements of the Bakassi Peninsula, Cameroon. Urban and Regional Planning.

Vol. 3, No. 1, 2017, pp. 11-19. doi: 10.11648/j.urp.20180301.13

Received: September 27, 2017; Accepted: October 14, 2017; Published: January 19, 2018

\begin{abstract}
Historicity, geo-strategic and economic bearing has snatched the discourse on border environments from contemporary geographical literature. Yet, these environments have stoutly become hotspots for violent expression of conflicting entitlements to natural resources and socio-economic opportunities. The Bakassi Peninsula at West Africa's lone gulf (of Guinea) which replicates par excellence, the combination of resource-space tussle and conflicting territorial claims and resolution approaches between Nigeria and Cameroon, has unravelled major trends and dynamics of commercial activities for communities within the area. Within this politically hotbed peninsula is Ekondo Titi, a commercial hub undergoing significant dynamics in the periods before, during and after the Bakassi Crisis, laid to rest by the Green Tree Accord whose political palliative was no economic panacea to the quantitative and qualitative trade responses in the area especially on the Cameroonian side. This study purposively sampled 100 respondents involving traders, farmers, council workers and other stakeholders in Ekondo Titi of Cameroon. A chi square analysis at 0.05 level of significance with a degree of freedom of 9, portrayed a significant association between commercial sector dynamics and border insecurity in Ekondo Titi especially as trade patterns assumed a three period pendula-like mood. Post crisis trends reveal an increasingly unaccounted and unofficial cash crop trade outflow towards Nigeria in the dearth of practicable road transport infrastructure, warehouses/storage tanks, and other domestic marketing infrastructure. Post crisis trade management exhibits the need for the government of Cameroon to set in robust confidence building measures while drastically enhancing on the transport and market infrastructure.
\end{abstract}

Keywords: Crops, Border, Ekondo Titi, Commerce

\section{Introduction}

The border concept as an entity has a deep rooted history in the social sciences from multidisciplinary (historical, geographical, socio-economic, anthropological and political lenses) analysis and approaches [1]. The meaning and categorization of borders lies in their objective or subjectively perceived function(s) such that they can be considered as an area of division and demarcation or alternatively of contact, exchange and integration. In the simplest expression, borders may separate or connect constituting an area of demarcation, separation or division, referred to by political geographers as a frontier or a boundary [2]. Borders thus constitute separating spaces of territorial sovereignty serving as a barrier to human, economic, cultural and social exchange and movement. For nations' interest, where border resources abound, extreme political or military confrontation erupts [3], although borders generally serve as areas of exchange, interaction and integration permitting a geographically wider, politically inclusive, and economically active and space in which heterogeneous identities exist and are encouraged to flourish [2]. Ordinarily, borders are areas of contact, exchange and integration that as in the case of Cameroon and Nigeria it is the Bakassi peninsula, where Ekondo Titi has grown into the 
economic capital of Ndian Division and perhaps has potentials to second Kumba in the South West Region. It is located between latitude $4.5^{\circ}$ and $5^{\circ} \mathrm{N}$ of the Equator and longitude $8^{\circ}$ to $9^{\circ} \mathrm{E}$ of the Greenwich Meridian at whose northeast is Dikome Balue, east and southeast is Mbonge northwest is Mundemba, west is Kombo Itindi and south is Bamusso.

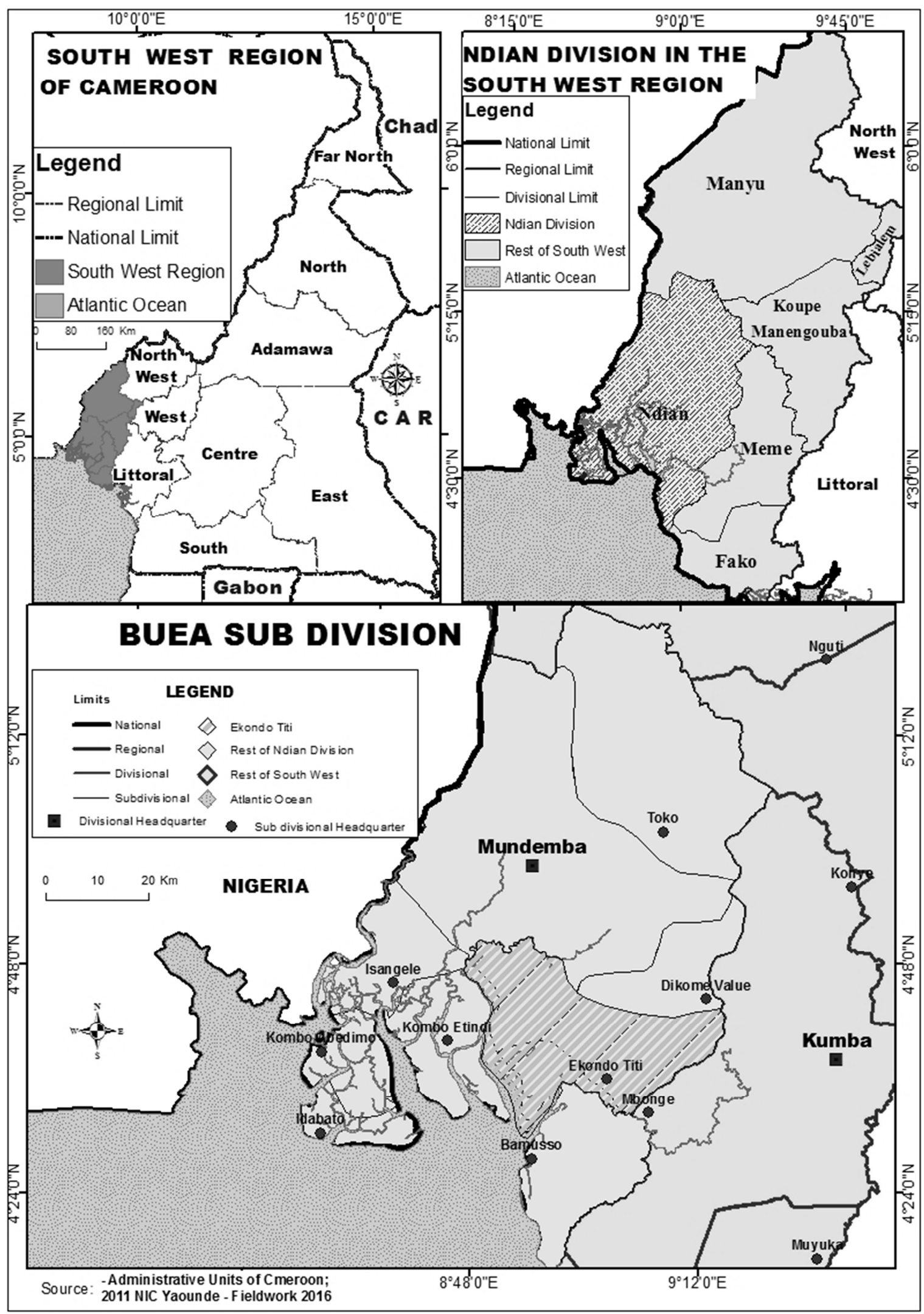

Figure 1. Location of Ekondo Titi in the South West Region. 
Such commercial sector is the core of economic growth and structural transformation. Growth in this sector's activities has become a focus of development policy in Sub-Saharan Africa and significant contemporary progress is made through building infrastructure and trade-related policies. The commercial sector has a huge potential for creating employment, catalysing investment and fostering growth in Africa. At the dawn of independence, most African nations introduced reforms which were meant to stimulate growth and development including the commercial sector [4]. This saw the creation of enabling environments for the free flow of trade across borders.

Trade flow trends in Africa are masked by difficulties in determining the actual role played by commercial activities in the growth of border towns [5]. There is nevertheless a widespread evidence of commercial activities in Sub-Saharan Africa border towns such as Somalia, Ethiopia and Kenya "[6], [7]" South Africa, Zimbabwe, Malawi, Zambia, Mozambique "[8], [9]", Congo “[10], [11]", and Equatorial Guinea-Cameroon [12].

The border trade dynamics examined in this study are the persistent changes in the volume and direction of flow of goods and services (exchange), and commercial infrastructure witnessed in the Bakassi area, specifically in Ekondo Titi between Cameroon and Nigeria. The Bakassi conflict affected the flow of goods between the two nations as most of the borders linking the two nations were blocked during the period of the crises and later reopened when the peninsular was handed to Cameroon. For instance, between 1993 when the crisis started 2006, trade flows of food crops, non-timber forest products and semi-finished products witnessed a significant drop by over 50\% [13].

The Cameroon-Nigeria border serves as the broader divide between West and Central Africa whose regional trade communities of the Economic Community of West African States (ECOWAS) and Central African Economic and Monetary Community (CEMAC) fostered teeming trade transactions in recent years. Political tensions between Cameroon and Nigeria since the 1960s have not obliterated the dynamism of international economic relations and especially regional cross border trade flows [14] with recent developments of infrastructure. Classical examples of border towns that have witnessed significant growth in Africa include the north-eastern Congolese market of Ariwara, the Ugandan town of Arua, and the Yei/Juba in southern Sudan [15]. In Cameroon, border towns such Mora in the Far North, Kribi and Kye-Ossi in the South, Douala in the Littoral, Idenau, Mamfe, Limbe and Ekondo titi in the South West Region continue to witness dynamics in commercial activities. Ekondo Titi, in the Bakassi Peninsula has witnessed changes in commercial activities from the 1980s both in type and volume of trade worthy of investigation.

\section{The Problem}

Cameroon border towns are economically active environments with a flow of goods and services such as Mamfe, Idenau, Ako, Kyé-Ossi, Kribi and Ekondo Titi.
Ekondo Titi's trend is a direct inverse replica of the Bakassi conflict while stakeholder responses are determined by the socio-political environment as noted in the CameroonEquatorial Guinea Kye-Ossi border [12], and partially attributed to transport sector evolution as in the Dumbo border town [16]. The case in point stems from an Ekondo Titi land use dynamics "[17], [18], [19]" and responses to a changing political collegiality between nations and regional economic blocs. These have invariably constrained economic development "[20], [17]" leading to a border natural resource harmonious development paradox "[21], [17]". This entangled problem web requires a probe into the trends and dynamics of this sensitive environment and its growth potential under stable conditions in keeping with the Green Tree Accord which insists on special public investment to boost trade and commerce amongst other things.

\section{Methodology}

In this study, we purposively sample 100 respondents in some neighbourhoods around the Ekondo Titi Port. The target population were those involved in commercial activities in Ekondo Titi ranging from the Ekondo Titi port, custom officers and workers of the Ekondo Titi Council. Based on an Ekondo population of some 5000 inhabitants [22], a 20\% sample was considered to representatively portray the level of trade and commercial activities. Traditional authorities and some village elders were interviewed for their experiences with the evolution of types of goods, volume and direction of flow, as well as infrastructural development. Descriptive statistical techniques were used as well as the association between commercial sector dynamics and border insecurity in Ekondo Titi and the dynamics of commercial activities and related challenges in Ekondo Titi through a chi square analysis at 0.05 level of significance and a degree of freedom of 9 .

\section{Presentation of Results}

\subsection{Trends and Dynamics of Commercial Activities}

Commercial activities witnessed significant swings changes between 1980 and 2016 in Ekondo Titi. Such changes can be grouped into three phases. The First phase that can be termed the Pre-Bakassi crisis period was seemingly characterised by a significant flow of goods to Nigeria. The second phase was the Bakassi crisis period (1993-2002) which saw a drop in the trade activities between Ekondo Titi and Nigeria giving way for a corresponding increase in the flow of goods and services towards Kumba. The third phase being the post Green Tree Accord period 2006 witnessed another upward shift in the type goods, volume and direction of flow to Nigeria. Of importance is the fact that the change was characterised by alterations in the type of goods, the flow direction of goods and the market infrastructures that are available to facilitate trade. Given the 
fact that the near border town of Ekondo titi represents a focal point for development in Ndian Division, an investigation on the trends and dynamics of commercial activities and the challenges was done.

The trends and dynamics are presented for three time periods on the basis of volume and direction of flow of goods, and the state of market infrastructure. These periods includethe Pre Bakassi (1980-1993), the Bakassi crisis (1993-2006) and the post Bakassi crisis period (2006-present). The PreBakassi crisis period corresponds to the years between 1960 (independence period) to 1993. This was a period which was characterised by significant trade flows through the Ekondo Titi beach market (Table 1).

Table 1. Main items supplied to Nigeria from Ekondo Titi between 1980 and 1994.

\begin{tabular}{llll}
\hline Item & Product & $\begin{array}{l}\text { Total flow of } \\
\text { goods (tons) }\end{array}$ & $\begin{array}{l}\text { Item total } \\
\text { (tons) }\end{array}$ \\
\hline \multirow{2}{*}{$\begin{array}{l}\text { Non-forest timber } \\
\text { products }\end{array}$} & Eru & 296402 & \\
& Bush Mango & 191990 & 653122 \\
& Snails & 149050 & \\
& Others & 15680 & \\
Food & Rice & 31320 & 1244742 \\
& Garri & 1037066 & \\
\hline
\end{tabular}

\begin{tabular}{llll}
\hline Item & Product & $\begin{array}{l}\text { Total flow of } \\
\text { goods (tons) }\end{array}$ & $\begin{array}{l}\text { Item total } \\
\text { (tons) }\end{array}$ \\
\hline \multirow{3}{*}{ Semi-finished } & Palm oil & 450 & \\
& Palm kernel & 651 & 1487 \\
& Rubber & 386 & \\
\hline & Others & - & \\
\hline
\end{tabular}

Source: Phytosanitary Brigade, Ekondo Titi and Fieldwork, 2017.

There was a regular flow of goods and services between Ekondo Titi and Nigeria. Traders from Ekondo could easily sell their food items and NTFPs as well as purchase semifinished and finished products from Nigeria. In addition, traders from other parts of Cameroon such as Kumba, Bafoussam and Douala moved into Ekondo Titi to buy goods. Most of these traders preferred the Ekondo Titi Nigeria channel because it gave them an opportunity to avoid paying huge charges as custom duties at the Douala port. Consequently, they preferred to make use of the Ekondo Titi port which served as an entrepot at the time. Based on the direction of flow, it was estimated that a majority of the traders in Ekondo Titi concentrated their dealings with Nigeria than with other towns such as Kumba. This was partly encouraged by the poor state of the Kumba-Ekondo Titi highway (Figure 2).

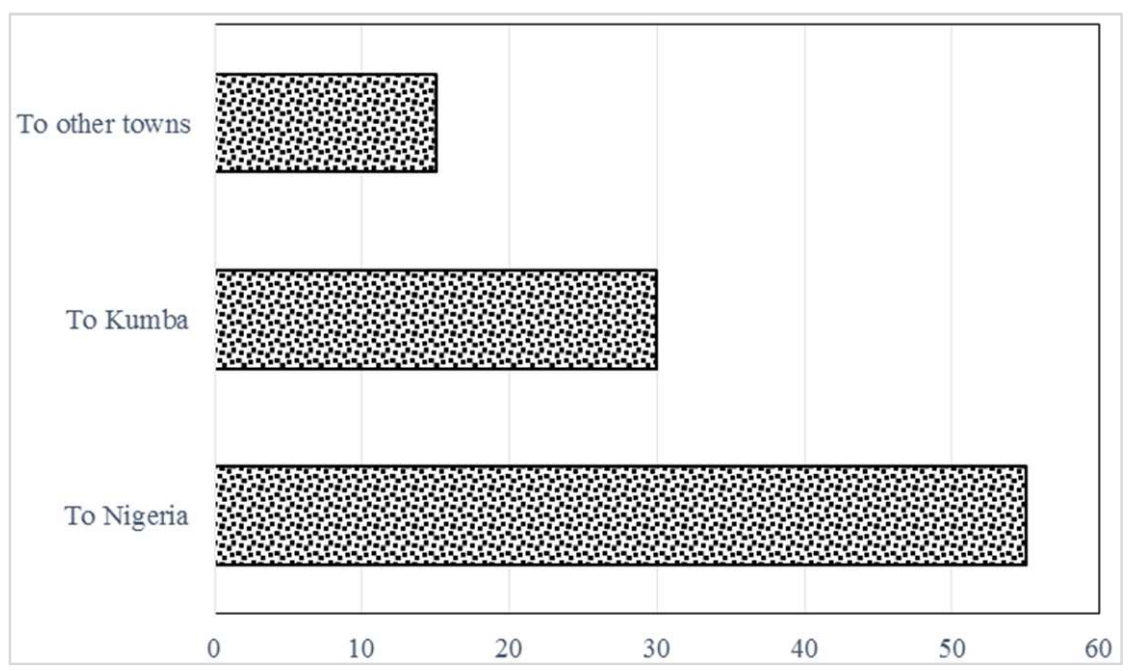

Figure 2. Direction of flow of goods during the pre-Bakassi crisis era.

The key infrastructure at the time include warehouses, markets, stores, storage tanks (palm oil) and a motorable road linking main town Ekondo Titi to Ekondo beach through Highway Quarters. Some of these structures have witnessed significant dilapidation (Table 4) and are out of use as of now. Their presence serves as a pointer to the effectiveness of trade activities during this period. The PAMOL palm oil storage tank for instance (Figure 3), with a storage capacity of 1800 tons, was used at the time to store oil for its eventual supply to Nigeria. With the drop in oil production, these tanks have, over the years remained unused since the 1990s.

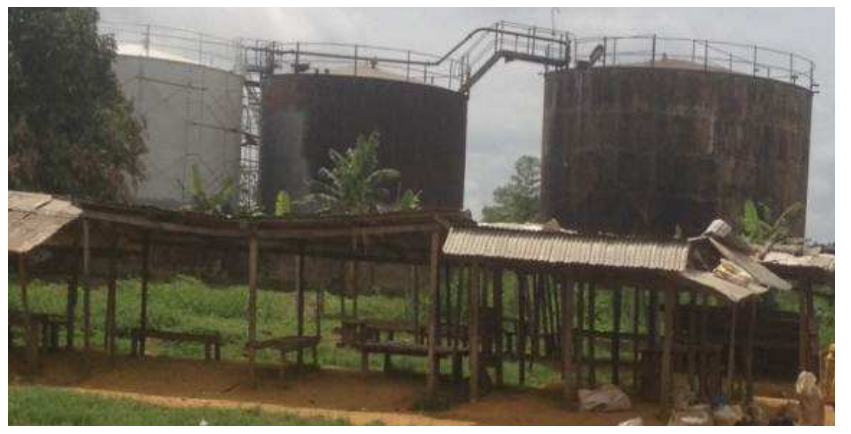

Source: Fieldwork, March 2017.

Figure 3. PAMOL Storage Tanks at the Ekondo-Titi Beach. 
The Bakassi crisis era was between 1993 and 2006. During the Bakassi crisis which began on 23 December 1993, most trading activities witnessed an ebb logically as a war zone any trade stakeholder in the region could be exposed to the war. Understandably there was a significant drop in goods supplied from Ekondo Titi to Nigeria and vice versa (Table 2 and Figure 4).

Table 2. Trade flows to Nigeria from Ekondo-Titi during the Bakassi crisis.

\begin{tabular}{lll}
\hline Item & Product & Total flow of goods (tons) \\
\hline & Eru & 148201 \\
Non-timber forest products total (tons) & 95995 \\
& Bush Mango & 74525 \\
& Snails & 7840 \\
Food & Others & 15660 \\
& Rice & 518533 \\
& Garri & 34947 \\
Semi-finished & Plantain & 53231 \\
& others & 150 \\
\hline
\end{tabular}

Source: [13] \& Fieldwork, 2017.

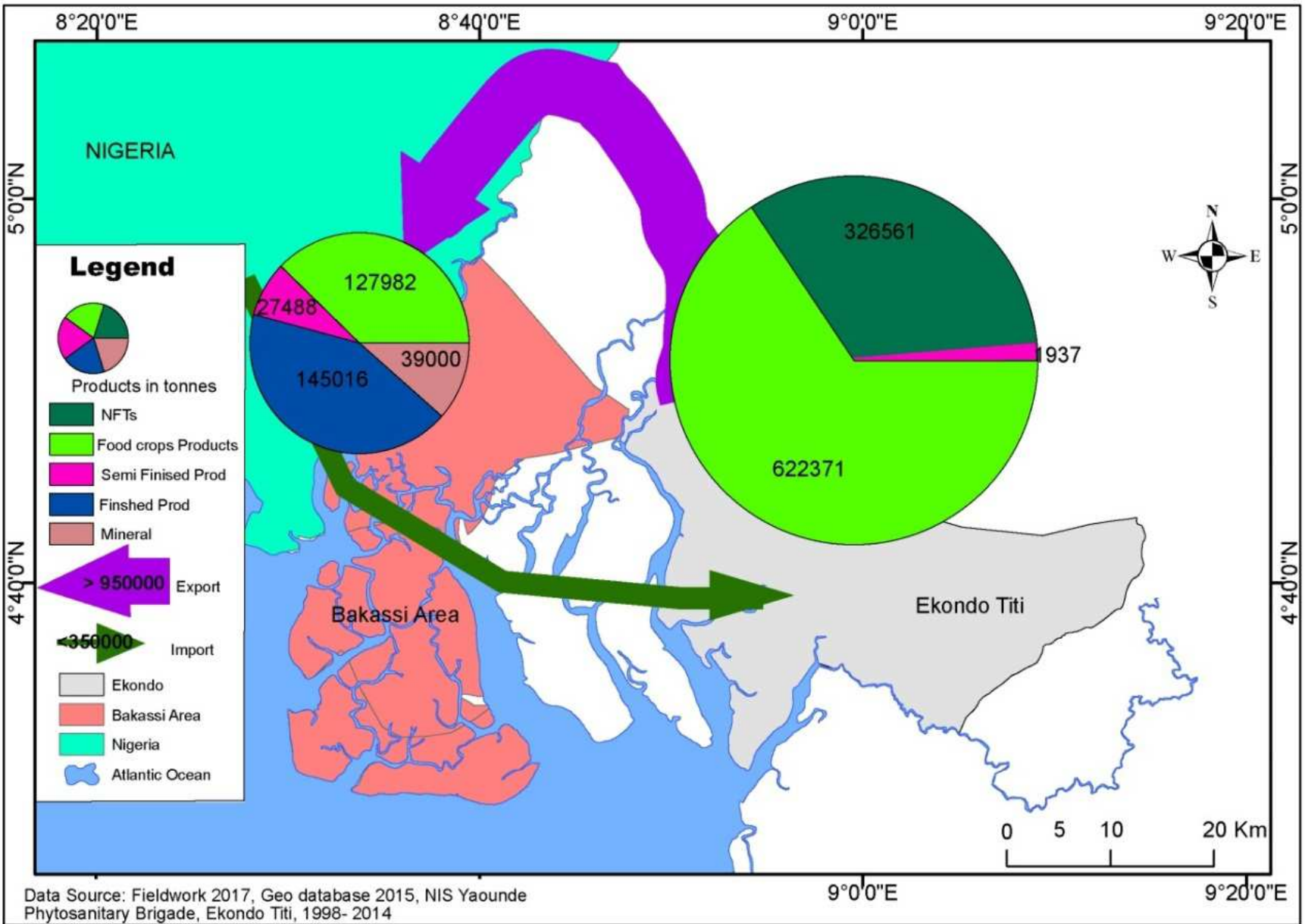

Figure 4. Trade flux between Ekondo Titi and Nigeria during the Bakassi Crisis.

The drop in the quantity of goods traded made some traders leave the activity completely. This negatively affected the state of commercial infrastructure as most of the warehouses and storage tanks were either under-utilised or abandoned (Figure 5). People found it difficult to bear the cost of renting or using warehouses and stores due to the fact that their scales of operation had dropped. 


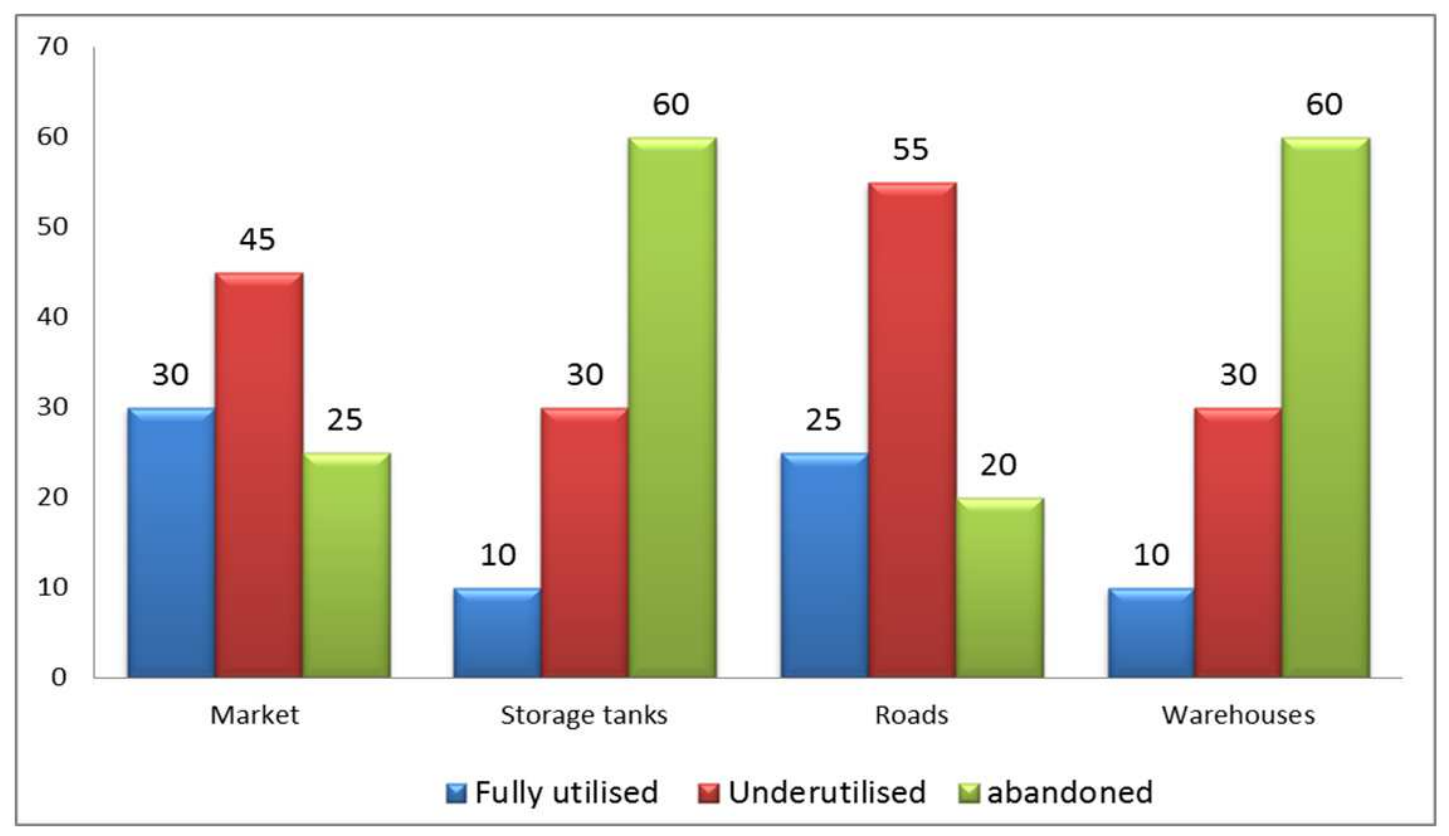

Figure 5. State of market infrastruture during the Bakassi Crisis.

The Post-Bakassi crisis era start between 2006 after the signing of the Green Tree Accord till present. Even after the resolution of the Bakassi crisis, there were still fears in the minds of traders as to whether future clashes will not ensue [17]. This contributed to create an initial standstill phase of commerce. As time went on, activities started gaining grounds, leading to an augmentation in the volume of flow in favour of the Ekondo Titi - Nigeria channel (Figure 6). It is important to note that the early phase of this period was characterised by a drop in the quantity of good traded since traders were not sure of the state of security (Table 3 ).

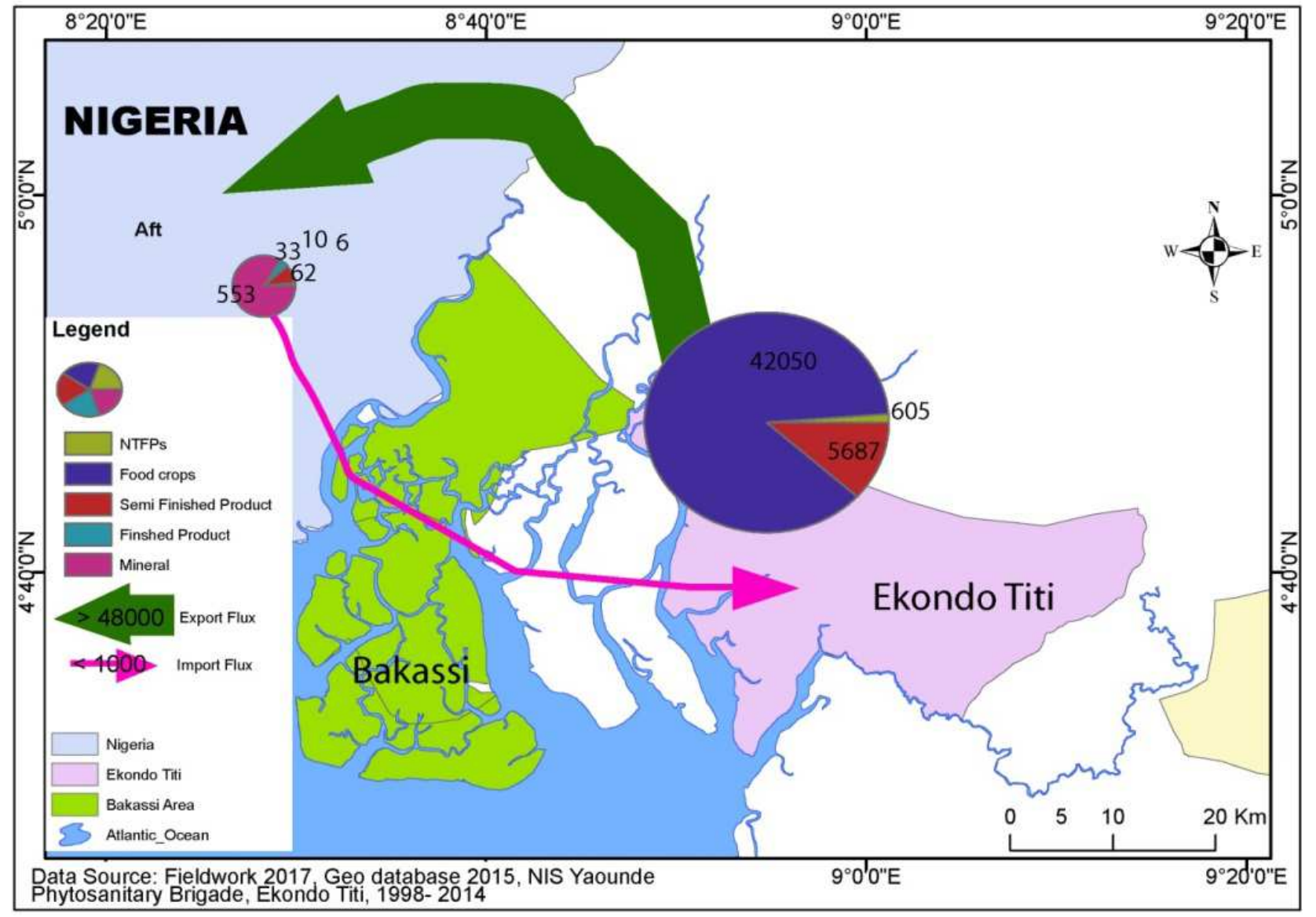

Figure 6. Trade flux between Ekondo Titi and Nigeria after the Bakassi Crisis. 
Table 3. Trade flows to Nigeria during the early post crisis period.

\begin{tabular}{llll}
\hline Item & Product & Total flow of goods (tons) & Item total (tons) \\
\hline \multirow{3}{*}{ Non-timber forest products } & Eru & 162 & 605 \\
& Bush Mango & 210 & \\
& Snails & 67 & 42049 \\
& Others & 166 & \\
Food & Rice & 41659 & 5687 \\
& Garri & 355 & 567 \\
& Plantain & 25 & 10 \\
Semi-finished & Others & 3288 & \\
& Palm oil & 208 & \\
& Palm kennel & 2191 & \\
\hline
\end{tabular}

Source: Estimates from Phytosanitary Brigade, Ekondo Titi \& Fieldwork, 2017.

This negatively affected the state of commercial infrastructure as most of the warehouses and storage tanks were under-utilised while some warehouses were abandoned (Table 4). As time went on and there were a series of confidence building measures such as the intensification of the patrol team, traders increasingly got back to business. Commercial activities are yet to gain the steam it had prior to the crisis.

Table 4. Evaluation of market infrastructure evolution in Ekondo Titi.

\begin{tabular}{llll}
\hline Element & State before crisis & State during crisis & State after crisis \\
\hline Market & Good & Deteriorating & Good \\
Storage tanks & Good & Deteriorating & Abandoned \\
Roads & Deteriorating & Deteriorating & Deteriorating \\
Warehouses & Good & Good & Abandoned \\
\hline
\end{tabular}

\subsection{Discussion of Results}

The dynamics of commercial activities in the border town of Ekondo Titi is liable to the fall in the prices of goods as triggered by the nature of transport network. This was complemented by a change in the demand of goods as a function of seasons (Table 5).

Table 5. Demand situation for products as a function of seasons.

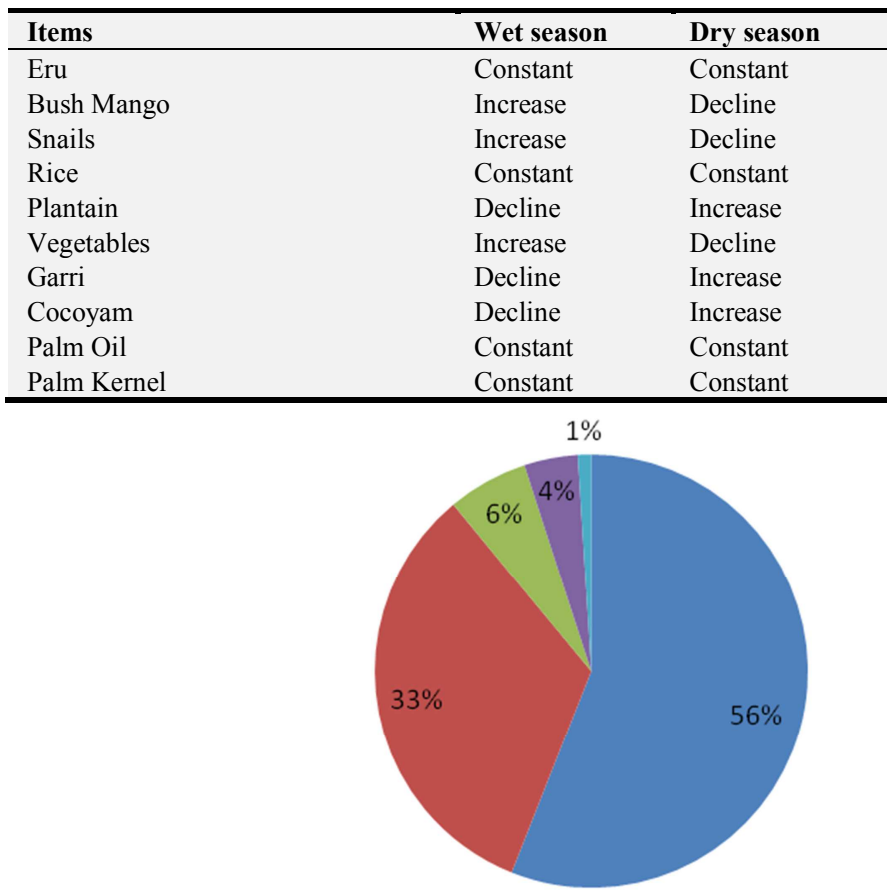

Such changes alter the demand and supply pattern especially of agricultural products. Incessant border checks and harassments as exemplified by the presence of numerous check points discouraged traders. High taxes discourage investments in the area (Figure 7). As a major contributor, the poor transport network in this area has been echoed in many cases "[18], [17], [20]". This factor alongside the Bakassi crisis account for almost $90 \%$ of the causes in the changes that have occurred in commercial activities in this area. Ekondo Titi known as the economic centre of Ndian division is endowed with a lot of economic potentials some of which include forest, agricultural and water resources [21]. The conversion of these potentials into economic development has been hindered by the underdeveloped road and maritime transport modes to ensure the flow and exchange of goods and services as vital ingredients for economic development and commercial activities.

Figure 7. Factors of commercial dynamics in Ekondo Titi.

\author{
Bakassi Crisis \\ - Poor transport network \\ Fall in prices \\ Change in the demand of goods \\ - Over control or high taxes
}


The most outstanding factor is border insecurity replicating from the Bakassi crisis even though border towns have an established tradition of economic stimulation which encourages trade and investment "[17], [12]". The border position of Ekondo Titi to neighbouring Nigeria has introduced a paradigm shift depicting much sensitivity and insecurity that negatively affects commercial activities in terms of volume and direction of flow of goods as well as the necessary infrastructure. Border insecurity reached its peak during the famous Bakassi crisis and lasted over a decade of skirmishes and gun battles with a resultant loss of lives and displacement of people. Such could only but slow down commercial interactions and transactions between Ekondo Titi with Nigeria especially as the numerous outlets/creeks that were hitherto very instrumental in trading activities prior to the crisis became strategic points for military manoeuvres and assault points of both nations sealing the livelihood of the riverine population [23] and directly negatively intensifying (Table 6) each time soldiers of Nigeria and Cameroon clashed [24] amounting to more than $50 \%$ (Figure 7) perception while road network made for only $30 \%$.

Table 6. Chi-Square Tests for Border insecurity and commercial sector dynamics.

\begin{tabular}{llll}
\hline & Value & df & Asymp. Sig. (2-sided) \\
\hline Pearson Chi-Square & $18.944^{\mathrm{a}}$ & 9 & .026 \\
Likelihood Ratio & 19.471 & 9 & .021 \\
Linear-by-Linear Association & 2.953 & 1 & .086 \\
N of Valid Cases & 100 & & \\
\hline
\end{tabular}

Table 6 shows a significant inverse association between border insecurity and commercial sector dynamics in Ekondo Titi $\left(X^{2}=18.944, \mathrm{df}=9, \mathrm{p}=0.026<0.05\right)$ as confirmed by the chi-square $\left(X_{\text {cal }}^{2}=18.944\right)$ being greater that the critical chi square $\left(X_{\text {crit }}^{2}=16.919\right)$.

This discussion above alludes to the active environments but very porous nature of the borders to maritime transport since most of the roads are earth roads are seasonal and some not just usable for long periods of the year during torrential rains which causes an increase in the increase prices of basic commodities and consequent economic slowdown in the wet season being a major challenge to the commercial sector dynamics in Ekondo Titi (Table 7).

Table 7. Chi-Square Tests for challenges to commercial dynamics.

\begin{tabular}{llll}
\hline & Value & df & Asymp. Sig. (2-sided) \\
\hline Pearson Chi-Square & $44.165^{\text {a }}$ & 20 & .001 \\
Likelihood Ratio & 43.275 & 20 & .002 \\
Linear-by-Linear Association & 2.136 & 1 & .144 \\
N of Valid Cases & 100 & & \\
\hline
\end{tabular}

There are clear challenges affecting the commercial sector in Ekondo Titi $\left(X^{2}=44.165, \mathrm{df}=20, \mathrm{p}=0.001(\mathrm{p}<0.05)\right.$ especially as the chi-square $\left(X_{\text {cal }}^{2}\right)$ is greater than the critical value $\left(X_{\text {crit }}^{2}=31.41\right)$. The fact that the key challenge here is border insecurity and poor transport network is just a slight a deviation in other parts of Africa like along the Zimbabwe -
South African border, where Karolia (2009 as cited in [25]) noted brutality of the forces of law and order at the border post to be a deterring factor affecting the volume of flow of goods. This is aggravated by cases of sexual harassment as women are forced to engage in transnational sex while their male counterparts are sodomised "[26], [27]".

\section{Conclusion}

The aim of this study was to examine the trends, drivers and challenges of commercial activities in the border town of Ekondo Titi. Results confirm that commercial activities have witnessed dynamics as exemplified by the changing volumes and direction of flow of goods and services. The key drivers of this dynamics include issues of border insecurity and the Bakassi Crisis, and poor transport network. The conclusion drawn is that there are observed changes in the volume and direction of flow of trade between Ekondo Titi and Nigeria during the pre Bakassi, the Bakassi and post-Bakassi crisis periods. Cognisant of the degree of freedom of 9 at 0.05 level of significance, there is a significant association between commercial sector dynamics and border insecurity in Ekondo Titi. At 0.05 level of significance, there exist significant challenges associated with the dynamics of commercial activities in Ekondo Titi. At this level of findings, it may perhaps be worthy to suggest that the government of Cameroon should consider to improve the road network linking Ekondo Titi and rest of Cameroon so as to enable it and the rest of the country stir its trade and commercial sector at the same time pursuing the border town development road map of the Ministry of Commerce to improve border town market infrastructure including warehouses and storage facilities especially at the Ekondo Titi beach. This would be an across-nationality confidence building mechanism amongst traders that would eventually peter out fear and negative security concerns.

\section{References}

[1] Cassarino, J. P. (2005). Approaching borders and frontiers: Notions and implications. Florence European University Institute, mimeo, 1-18.

[2] Newman, D. (2001). Borders and bordering: towards an interdisciplinary dialogue. European Journal of Social Theory, Vol. 9 (2), pp. 171-186.

[3] Ngalim, A. N. (2016). African boundary conflicts and international mediation: The absence of inclusivity in mediating the Bakassi peninsula conflict. African Peace building Network, Working Paper No. 9, September 2016, pp $1-27$.

[4] Kimengsi, J. N. \& Fombe, L. F. (2015). The Growth pole strategy as a panacea for sub-Saharan Africa's regional development challenges: Reflections from Cameroon and Nigeria. Journal of Sustainable Development in Africa, Volume 17 (8), 2015, http://www.jsd-africa.com/ISSN: 15205509 pp 79-90. 
[5] Mukhtar, A. and Mombert, H. (2013) Where informal procedures are quasi-formal - cross border trade between West and Central Africa. Africa Trade Policy Notes, May 2013 pp 1-9.

[6] Little, P. D. (2005). Unofficial trade when states are weak: The case of cross border commerce in the Horn of Africa, Helsinki: WIDER Research Paper No. 2005/13, pp1-26.

[7] Teka, T. and A. Azeze (2002). Cross-border trade and food security in the Ethiopia Djibouti And Ethiopia-Somalia Borderlands, Addis Ababa, Ethiopia: OSSREA Development Research Report Series, No. 4.71pp.

[8] Ndlela, D. B. (2006). Informal cross-border trade: The Case of Zimbabwe, Johannesburg, South Africa: Institute for Global Dialogue, Occasional Paper, No. $52 ., 59$ pp.

[9] Mijere, N. J. N. (2009) Informal cross border trade in the Southern African Development Community (SADC), Addis Ababa: Organization for Social Science Research in Eastern and Southern Africa, $22 \mathrm{pp}$.

[10] MacGaffey (ed.) (1991). 'The Real Economy of Zaire'. London \& Philadelphia: James Currey \& University of Pennsylvania Press pp 13-14.

[11] Kabamba, P. (2012). Business of Civil War: New Forms of Life in the Debris of the Democratic Republic of Congo, Dakar: CODESRIA. 23rd August 2010, 24 pp.

[12] Fogwe, Z. N. (2017). Stakeholder and partnering strategies of national border town functions at Kyé-Ossi, South Region, Cameroon, Journal of Geography, Meteorology and Environment, A publication of the Department of Geography and Meteorology, Nnamdi Azikiwe University, Awka, Nigeria, Vol. 2, No 1, ISSN 2449-2011, pp. 1-10.

[13] Phytosanitary Brigade Report for Ekondo Titi, 2017.

[14] Loser, C. M. (2009). Cross-border trade and investment among emerging economies. Global Journal of Emerging Market Economies, 2009, Vol. 1, Issue 1, pp 43-62.

[15] Titeca, K. (2009). The Changing cross-border trade dynamics between north-western Uganda, north-eastern Congo and southern Sudan. The Journal of Modern African Studies 47 (2), 291-317, 2009.

[16] Fogwe, Z. N. and Ntoban V. K. (2017). Cameron-Nigeria border settlement dynamics: trends and perspectives from Dumbo (North West Region of Cameroon), in Ba'ana Etoundi, M. L (Ed) Dynamiques urbaines et transformations sociospatiales au Cameroun: Regards croisés entre logiques, stratégies et pratiques d'acteurs, Editions CAD. pp 47-79.

[17] Kimengsi, J. N. (2011). Spatial economic disparity and implications for development in the South West Region of
Cameroon" PhD Thesis in Geography, University of Buea, 320pp.

[18] Kimengsi, J. N. (2008). The contribution of PAMOL Plantations and its associated environmental impacts to the development of Ekondo Titi Sub Division, South West Region of Cameroon. PhD Thesis in Geography, University of Buea 202pp.

[19] Etongo, B. D (2007). Land use dynamics and vegetation change in Ekondo-Titi Subdivision S. W province of Cameroon. Unpublished M. Sc. Thesis, FSMS Department of Geography, University of Buea, 210pp.

[20] Kometa, S. S. and Kimengsi, J. N. (2013). Transport as an impediment to the development of an economically endowed region: The case of Ekondo- Titi Sub-Division, Cameroon. Greener Journal of Environmental Management and Public Safety Vol. 2 (1), Lagos Nigeria. Available at http://gjournals.org/Adverts.html pp. 032-039.

[21] Kimengsi J. N \& Lambi, C. M (2015). PAMOL plantations: Prelude to a looming population problem in Ekondo Titi Subdivision, South West Region of Cameroon, Journal of Sustainable Development in Africa, Vol. 17(3), 2015 pp 239249.

[22] Ekondo Titi Council Development Plan, 2011.

[23] Ariye, E. C. (2015). Nigeria, Cameroon and the Bakassi territorial dispute settlement: The triumph of bilateralism. International Affairs and Global Strategy Vol. 38, pp 24-33. www.iiste.org ISSN 2224-574X (Paper) ISSN 2224-8951 (Online).

[24] Baye, F. M, (2010). Implications of the Bakassi conflict resolution for Cameroon' Africa Journal on Conflict Resolution, Vol. 10 (1), pp 9-34.

[25] Chirau, T. J. and Chamuka, P. (2013). Politicisation of urban space: Evidence from women informal traders at Magaba, Harare in Zimbabwe. Global Advanced Research Journal of History, Political Science and International Relations Vol. 2(2) pp. 014-026, May, 2013.

[26] Tay. N. (2010). Women traders confronting sexual harassment at borders. Available online: http://south-south.ipcundp.org/news/item/384-women-traders-con fronting sexualharassment-at-borders [Accessed: 2 October 2011]. 14pp.

[27] Matakanye J. (2011). Ten raped on SA border daily: officials Available online: http://www.newzimbabwe. Com/news5187-

10\%20raped $\% 20$ on $\% 20 \mathrm{SA} \% 20$ border\%20daily\%20officials/ news.aspx [Accessed: 2 October 2011]. 